\title{
The Influence of E-Learning towards Students' Heutagogy Skills in Higher Education
}

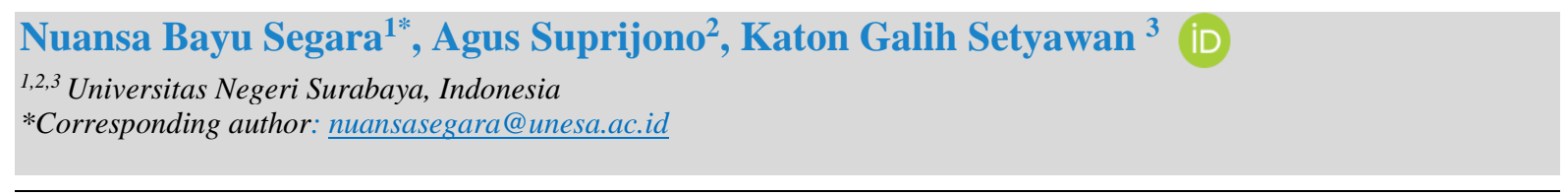

\begin{abstract}
Heutagogy skills are needed by students to take part in the e-learning process during the Covid-19 pandemic. This study examines the measurement model and proved the influence of e-learning towards self-directed, self-regulated, and selfdetermined learning skills. This research uses a survey method, the data is collected through an online questionnaire which shared with 232 respondents. The research instrument validity was tested by Confirmatory Factor Analysis (CFA) and reliability test by calculating Cronc'bach value. Path Analysis with AMOS 21.0 was used to analyze the relationship between variables. The result confirms that e-learning significantly affected self-regulated learning. Meanwhile, selfregulated learning has a significant effect on self-determined. Path analysis result indicated that e-learning significantly affected self-determined learning if self-directed and self-regulated learning is first developed. The results of this study also provided an empirical basis for other researchers who want to develop independent learning in students through e-learning. Indicators in self-directed learning can be developed in an online learning process, hence, it can be observed directly on student learning outcomes.
\end{abstract}

Keywords: e-learning, self-directed, self-regulated

\begin{tabular}{lll}
\hline History: & & Publisher: Undiksha Press \\
Received & : March 16, 2021 & Licensed: This work is licensed under \\
Revised & : March 20, 2021 & a Creative Commons Attribution 3.0 License \\
Accepted & : June 08, 2021 & Published \\
: July 25, 2021 &
\end{tabular}

\section{INTRODUCTION}

Adult self-learning is known as Heutagogy or self-determined learning (SDL). The essence of Heutagogy is: in the learning situation, the focus must be what and how the student wants to learn, not what was have taught to them. Therefore, this approach is very different from the more formal and traditional ways of teaching. In the Heutagogy approach: the educational process changes from being a process where educated people (teachers, teachers, lecturers) pour information into the heads of students to a place where students choose what to learn and even how they can learn it (Hase \& Kenyon, 2013). These selfdetermined learning skills are very relevant to the online learning process because their characteristic is independent learning (Blaschke, 2013; Can, 2012). Other abilities that form self-determined learning are self-directed and self-regulated learning.

Self-regulated learning (SRL) is the process by which students build knowledge with metacognitive control, regulating mental content and external environmental factors. The object monitoring metacognitive includes cognition, decision-making, planning, motivation, affect, and emotion (Winne, 2015, 2016). Self-regulation is one of the essential components of independent learning. Students can learn the ways of self-learning, identified obstacles, and foster learning skills (Pintrich, 1995). E-learning requires students to do independent learning: lecturers provide signs and resources for the content. Furthermore, students search for information, plan the lessons, set goals, and manage self-motivation. Positively, Selfregulated learning specifies the self-directed learning of students; this skill is necessary for the E-Learning process (Brookfield, 2009). Self-directed learning (SDRL) is an approach when students are motivated to assume responsibilities and collaborative control from the 
cognitive rule and contextual to build (self-management) and reaffirmed the result of meaningful and useful learning (Garrison, 1997). That can view much research focused examine self-directed learning for the E-learning process (Beach, 2017; Esham \& Abdul, 2010).

Based on the literature review, that leading research to explore three concepts relates to Heutagogy skills in the various kinds of education, self-directed learning (Bracey, 2010; Cadorin et al., 2013; Robinson \& Persky, 2020; Williamson, 2007; Zhoc \& Chen, 2016), self-regulated learning (Arbor \& Greet, 2000; Barnard et al., 2009; Boekaerts \& Boekaelrts, 2017; Martin, 2004; Reed, 2014; Sinatra, 2014; Winne, 2015, 2016). Self-determined learning (Hase, 2016; Hase \& Kenyon, 2013; Kellenberg et al., 2019; Müller \& Louw, 2004). The three concepts described above are continuity in the learning process, especially independent learning such as e-learning carried out during the Covid-19 Pandemic. Currently, research about heutagogy skills focuses on how related these to others variables. A research result shows a significant effect among self-directed learning with student interaction on the online learning environment and their difference in student interaction on the online learning environment based on self-directed learning readiness (Lasfeto \& Ulfa, 2020). The other result, motivation is needed to develop self-determined skills in studentcentered learning practice. So as in the e-learning process to use assessment for learning would improve motivation to do self-determined learning (Kulakow \& Raufelder, 2020) so in e-learning to use assessment for learning would to improved motivation to do selfdetermined learning (Chemsi et al., 2020).

Based on current research, the gap in the heutagogy skills studies is not available to research to prove relational construct in the heutagogy concept with e-learning. While the 2000-2010 period, researchers focused define and find out indicators from the pedagogy concept. Furthermore, in the 2011-2020 period, many researchers constructed a measurement model. At the same time, they are tried to identification affected factors that develop selfdirected, regulated, and determined learning. Now, the trend of Heutagogy Skills research is how to develop student skills by e-learning. Accordingly, important to confirmed linkages pedagogy concepts in the e-learning process. What is the e-learning process affected pedagogy skills? Self-directed learning and self-regulated learning are the provisions needed by students to develop self-determined skills. That means that there needs to be a measurement model that can predict the relationship and influence between these variables. The aim of this research is to find out the measuring model of Heutagogy learning skills. The results were expected by learners to be a reference for developing E-learning in the future.

\section{MATERIALS AND METHODS}

This study applies a quantitative approach with survey research methods. This study focuses to analyse the influence between variables. The measurement model consists of four variables: E-learning and SDLR are latent variables, SRL is the moderator variable, SDL is the manifest variable. The population in this research is all students of the social studies education program. Quotation of the sample by saturated sampling, which means 232 students participated in this research. The instrument used to collect data is a Likert questionnaire scale with a 1-5 rating. The questionnaire formatting by Google form and shared in the Google class. Table 1 describing the dimension in each variable that applies in the instrument.

This study uses confirmatory factor analysis (CFA) to test the validity of each instrument. This technique can accurately test the construct validity of each variable under study. CFA will look at the correlation value of each item to the total value. Calculations in the CFA are assisted by SPPS 18.0. Valid items are items whose $r$ value is> 0.30 (Kusnendi, 2008). Reliability testing of each questionnaire in this study was calculated by estimating 
Cronc's Alfa value. The estimation of this value is assisted by SPSS 20.0. Reliability test to determine the consistency of the measurement instrument for each variable in this study. Cronbach Alpha value of each variable must be $>0.70$ to be the instrument is reliable. The data analysis technique used in this study is path analysis. That is used to test whether a model is fit or not. The model measured in this study is a linear relationship between variables. Testing of this model was carried out by AMOS 21 software. Besides, path analysis makes it easier to see the estimation results of the influence between variables measured in this study.

Table 1. Variable and Dimension of Measurement Model

\begin{tabular}{llll}
\hline \multicolumn{1}{c}{ Variables } & \multicolumn{3}{c}{ Dimension } \\
\hline E-Learning & $\begin{array}{l}\text { Learning Plan; Content; Learning Methods; Media; } \\
\text { Assessment }\end{array}$ & & \\
SDLR (Self-directed & Awareness; Learning strategies; Learning activities; \\
learning) & Evaluation; Interpersonal skills & & \\
SRL (Self-regulated & Environment structuring; Goal setting; Time management; \\
learning) & Help-seeking; Task strategies; Self-evaluation & \\
SDL (Self-determined & Self-efficacy; Communication; Collaboratively; Creative; \\
learning) & Positive value & \\
\hline
\end{tabular}

\section{RESULTS AND DISCUSSION}

\section{Results}

The variables in this study consisted of four variables, namely X1 (e-learning); X2 (SDLR: Self-directed learning); and Y1 (SRL: Self-regulated learning), and Y2 SDL (Selfdetermined learning). Before data analysis, the instrument used to measure the four variables was tested for validity and reliability. This CFA (Confirmatory Factor Analysis) procedure is used to test the constructs of each variable. The measurement model result on e-learning construct, self-directed learning, self-regulated learning, and self-determination all fulfill the construct validity requirements because the critical ratio value is $>1.96$. Those all indicators that form the e-learning construct can reflect the forming variables. All indicators that reflect each variable determining the e-learning construct show good significance because the probability value is 0.00 , which means $<0.001$.

Tabel 2. The Result of Instrument Reliability

\begin{tabular}{lc}
\hline \multicolumn{1}{c}{ Variable } & Cronbach's alpha \\
\hline X1-E-Learning & 0,933 \\
X2-SDRL (Self-directed learning) & 0,927 \\
Y1-SRL (Self-regulated learning) & 0,919 \\
Y2-SDL (Self-determined learning) & 0,948 \\
\hline
\end{tabular}

The Cronbach alpha value of the e-learning variable is 0,933 (good criteria); the Selfdirected learning variable is 0,927 (good criteria); the Self-regulated learning variable is 0,919 (good criteria); Self-determined learning variable is 0,948 (good criteria). It can be concluding that these four variables have good validity and reliability, without a single item of research instrument being dropping because it is considered invalid. Table 2 shows the values of Cronbach alpha four variables. After testing the validity and reliability of the data collection results, the next step is to carry out path analysis, where this path analysis serves to 
determine or explain the direct and indirect effects of a set of variables, as a causal variable on an inclination of other variables which are consequential (Haryono \& Octavia, 2020). Figure 1 below is the measurement model that has been estimated. Summary of parameters provides information about the summary of parameters estimated and not estimated. It can be informed that in the model there are 14 parameters, consisting of 4, not estimated parameters and 10 estimated parameters. The 4 parameters that were not estimated were the regression weight coefficient or path coefficient of the residual or unobserved exogenous variables (e1, $\mathrm{e} 2$, e3, e4). The regression weight coefficient for these 4 variables is not estimated because the value has been fixed at 1 . The 10 parameters that are estimated are 5 regression weights or path coefficients, 1 covariance or correlation coefficient, namely the correlation between $\mathrm{X} 1$ and $\mathrm{X} 2$, and 4 variances, namely exogenous variable variance observed $\mathrm{X} 1$ and $\mathrm{X} 2$, and unobserved exogenous variance e 1 and e2.

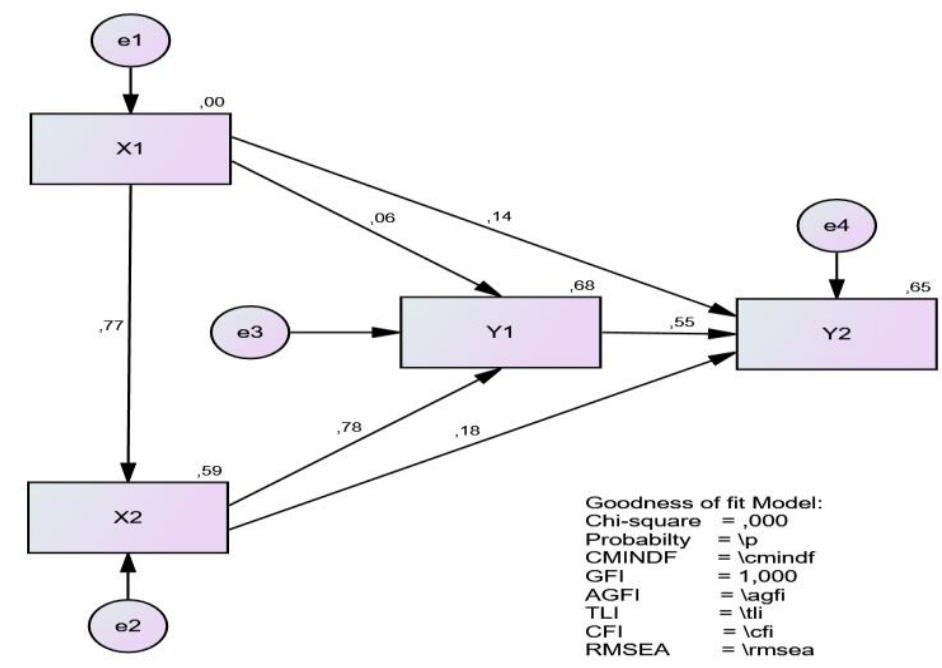

Figure 1. Measurement Model on the influence of E-Learning towards Self-Directed, SelfRegulated and Self-Determined Learning after Estimation

Summary of parameters provides information about the summary of parameters estimated and not estimated. It can be informed that in the model there are 14 parameters, consisting of 4, not estimated parameters and 10 estimated parameters. The 4 parameters that were not estimated were the regression weight coefficient or path coefficient of the residual or unobserved exogenous variables (e1, e2, e3, e4). The regression weight coefficient for these 4 variables is not estimated because the value has been fixed at 1 . The 10 parameters that are estimated are 5 regression weights or path coefficients, 1 covariance or correlation coefficient, namely the correlation between X1 and X2, and 4 variances, namely exogenous variable variance observed X1 and X2, and unobserved exogenous variance e1 and e2. Based on the output of the assessment of normality text, information is obtained that, in a multivariate manner, the distribution pattern of the research variable data does not follow the normal distribution because the CR value is 9.231 which means that the $\mathrm{CR}$ is greater than the value of \pm 1.90 (the crisis value of the $\mathrm{z}$ table is at an error rate of 0.05 ). It can be concluded in multivariate, the distribution pattern of the research variable data tends not to be normally distributed. Therefore, it is possible to use a more robust estimation method against data abnormalities, by using the GLS, ULS, or ADF techniques. However, not all research data can be analyzed by this method because of the problem of sample size. Because the number of samples in this study was 243 respondents, therefore, GLS (Generalized Least Squares) technique was used. 
Model parameter estimation can be done by looking at the estimated value of the correlative relationship between variables. It can be seen from the results of the estimated value of X1 and X2 which have an R-value of 0.77 , the estimated value of X1 and $\mathrm{Y} 1$ has an $\mathrm{R}$-value of 0.06 , the estimated value of $\mathrm{X} 2$ and $\mathrm{Y} 1$ has an $\mathrm{R}$-value of 0.78 . The estimated value of $\mathrm{X} 1$ and $\mathrm{Y} 2$ has an R-value of 0.14 . Furthermore, the estimated value of $\mathrm{X} 2$ and $\mathrm{Y} 2$ has an R-value of 0.18. Furthermore, the estimated value of $\mathrm{Y} 1$ and $\mathrm{Y} 2$ has an R-value of 0.55 . It can be seen that the measurement model is saturated or perfect fit, hence, CMIN/DF, TLI and CFI, and RSMEA cannot be calculated. This means that there needs to be a modification of the measurement model. If you look at the measurement results, what needs to be removed is the path coefficient between $\mathrm{X} 1$ and $\mathrm{Y} 1$ because it has a low correlative relationship. The following figure is a modified measurement model.

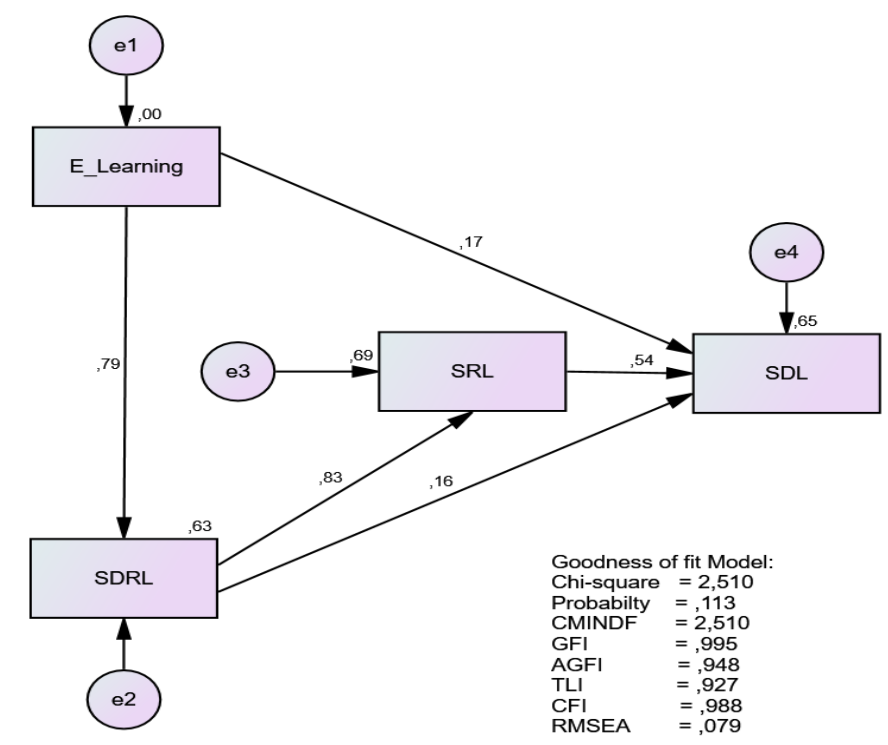

Figure 2. Measurement Model on the influence of E-Learning towards Self-Directed, SelfRegulated and Self-Determined Learning after Modification

After modification, the criteria for estimating the fit of the CMIN/DF, TLI and CFI, and RSMEA models appear and can be calculated. The following table shows the results of the path analysis model estimation in this research.

Table 3. Fit Model Test of the Influence of E-Learning towards Self-Directed, SelfRegulated and Self-Determined learning

\begin{tabular}{lcc}
\hline \multicolumn{1}{c}{ Fit Model Criteria } & Cut off Value & Values \\
\hline $\mathrm{X}^{2}$ & - & 2,510 \\
$\mathrm{X}^{2} / \mathrm{Sd}(\mathrm{CMIN} / \mathrm{DF})$ & $\leq 2,00$ & 2,510 \\
Probability & $\geq 0,05$ & 0,113 \\
RMSEA & $\leq 0,08$ & 0,079 \\
GFI & $\geq 0,90$ & 0,995 \\
AGFI & $\geq 0,90$ & 0,948 \\
TLI & $\geq 0,95$ & 0,927 \\
CFI & $\geq 0,95$ & 0,988 \\
\hline
\end{tabular}

The overall fit model test results provide a significance level (p-values) of $\mathrm{n} 2$ at degrees of freedom 2 of 0.318 or $31.8 \%$, far above the acceptable error rate $(0.05)$. It can be seen from the goodness fit criteria of other models, the values of GFI, AGFI, TLI, and CFI 
are all greater than 0.90. All of this shows that the model after being repaired is fit with the data. In other words, the model after being improved is able to estimate the population correlation matrix which tends not to be different from the sample correlation matrix. Individual test results showed that all path coefficient estimates obtained were very significant ( $\mathrm{p}<0.05$ ). Even though there is a path that is released from the model, the model is still able to provide an explained variance (R2) of endogenous variables of 0.688 or $68.8 \%$ and 0.650 or $65 \%$. Y1 is very significant and positively influenced by X2. The magnitude of the influence of $\mathrm{X} 2$ on $\mathrm{Y} 1$ is $(0.830)^{2}=0.688$ or $68.8 \%$. Then the following model can be produced $\mathrm{Y} 1=0.793 \mathrm{X} 1+0.830 \mathrm{X} 2$. $\mathrm{X} 2$ is significantly and positively influenced by $\mathrm{X} 1$. The amount of $\mathrm{X} 1$ to $\mathrm{X} 2$ is $(0.793)^{2}$ which means 0.628 or $62.8 \%$. Then the following model can be generated $\mathrm{X} 2=0.793 \mathrm{X} 1$. Simultaneously $\mathrm{Y} 2$ is significantly influenced by $\mathrm{X} 2$ that is 0.688 or $68.8 \%$ and is significantly influenced by $\mathrm{Y} 1$ of $(0.830)^{2}=0.688$ or $68.8 \%$. Then it will produce a calculation model like this $\mathrm{Y} 2=0.589 \mathrm{X} 2+0.688 \mathrm{Y} 1$. After making a conclusion on the results of the path analysis estimation, it is necessary to test the hypotheses that have been previously proposed. There are six hypotheses that will be tested in this study. Hypothesis testing that is done is a significance test between the influenced variables. The following table shows the hypothesis, the dissertation with $\mathrm{R}$ values, standard errors, $\mathrm{p}$ values, and conclusion.

Table 4. Hypothesis, R-value, Standard Error, P Values, and Hypothesis Test Conclusion

\begin{tabular}{llcccc}
\hline No & \multicolumn{1}{c}{ Hypothesis } & $\mathbf{R}^{2}$ & se & P values & Conclusion \\
\hline 1 & $\begin{array}{l}\text { There is a significant influence of online } \\
\text { learning on self-directed learning }\end{array}$ & 0,628 & 0,039 & 0,000 & Received \\
2 & $\begin{array}{l}\text { There is a significant influence of online } \\
\text { learning towards self-regulated learning. }\end{array}$ & 0,008 & 0,068 & 0,316 & Rejected \\
3 & $\begin{array}{l}\text { There is a significant influence of self- } \\
\text { directed learning on self-regulated learning }\end{array}$ & 0,689 & 0,043 & 0,000 & Received \\
4 & $\begin{array}{l}\text { There is a significant influence on online } \\
\text { learning towards self-determined learning. } \\
\text { There is a significant influence of self- }\end{array}$ & 0,029 & 0,084 & 0,006 & Received \\
$\begin{array}{l}\text { directed learning towards self-determined } \\
\text { learning } 0,025\end{array}$ & 0,120 & 0,074 & Rejected \\
$\begin{array}{l}\text { There is a significant influence of self- } \\
\text { regulated learning towards self-determined } \\
\text { learning. }\end{array}$ & 0,289 & 0,079 & 0,000 & Received \\
\hline
\end{tabular}

The first hypothesis is to test the significant influence of online learning on selfdirected learning, the results are accepted. This is because of the $\mathrm{R}^{2}$ value of 0.628 with a Pvalue of $<0.05$, it can be stated that online learning variables have a very significant influence on self-directed learning with a determination coefficient of $62.8 \%$. The second hypothesis is to test the significant influence of online learning on self-regulated learning, the results are rejected. This is because the $\mathrm{R}^{2}$ value of 0.008 is very low, almost non-existent with a $\mathrm{P}$ value $<0.05$, it can be stated that online learning variables do not significantly affect selfregulated learning with a determination coefficient of $0.8 \%$. The third hypothesis is to test the significant influence of self-directed learning on self-regulated learning, the results are accepted. This is because the $\mathrm{R}^{2}$ value of 0.689 which is high enough with a value of $\mathrm{P}=$ 0.000 meaning $\mathrm{P}<0.05$, it can be stated that the self-directed learning variable has a very significant effect on self-regulated learning with a determination coefficient of $68.9 \%$. The fourth hypothesis is to examine the significant influence of online learning on selfdetermined learning. The results are accepted. This is because of a low $\mathrm{R}^{2}$ value of 0.029 
with a P-value $=0.006$, it means that the $\mathrm{P}$-value is still $<0.05$, it can be stated that online learning variables do not significantly affect self-determined learning with a determination coefficient of $2.9 \%$. The fifth hypothesis is to test the significant influence of self-directed learning on self-determined learning. The results are accepted. This is because the $\mathrm{R}^{2}$ value of 0.025 is quite low with a value of $\mathrm{P}=0.074$, which means $\mathrm{P}>0.05$, it can be stated that the self-directed learning variable does not significantly affect self-regulated learning with a determination coefficient of $2.5 \%$. The last hypothesis is to examine the significant influence of self-regulated learning on self-determined learning. The results are accepted. This is because the $\mathrm{R}^{2}$ value of 0.289 is moderate with a value of $\mathrm{P}=0.000$, which means $\mathrm{P}<0.05$, it can be stated that the self-regulated learning variable significantly affects self-determined learning with a determination coefficient of $28.9 \%$.

\section{Discussion}

Theories and research on self-regulated learning (SRL) began to appear in the 1980s and developed in the 1990s (Pintrich, 1995; Schunk, 1995; Zimmerman, 1990). Selfregulated learning, or self-regulation, is "an active constructive process in which learners set goals for their learning and then attempt to monitor, regulate, and control their cognition, motivation, and behavior, guided and constrained by their goals and contextual features in the environment" (Pintrich, 2000). Self-regulated learning by students will involve three features: the use of self-regulated learning strategies, their responsiveness to self-oriented feedback about learning effectiveness, and their interdependent motivation process. That means selfregulated learning is a process of students controlling their behavior, motivation, and thoughts in a learning process. So far, self-regulated learning has been widely applied in regular education, which emphasizes face-to-face learning. During the Covid-19 Pandemic, academic activities use online learning. If these self-regulating learning skills are important for successful learning in traditional face-to-face classrooms, it can be expected that these self-regulated learning skills will play a more important role in online learning (Barnard et al., 2009). Online learning is closely related to independent learning. Students need to regulate the learning process themselves, therefore, the goals of learning are achieved.

The path analysis model proposed is proven to meet the criteria for a model that is fit with the data. This means that the model can estimate the correlation between the variables proposed in this study. In confirmatory factor analysis (CFA) which is conducted to determine the factors that influence e-learning, it can be confirmed that the factors proposed, namely learning plan, content, learning methods, learning media, and assessment, are all valid and fit with the data. This means that these factors can represent e-learning in a construct. Previous research has divided the e-learning component into three factors, there are pedagogical models, instructional strategies, and learning technologies (Aparicio \& Bacao, 2013). Based on this concept, this research is divided from three factors into five factors fragment from these three components: pedagogical models into learning plans, assessments. Instructional strategies become learning methods and content. Meanwhile, learning technologies are called learning media. All of these factors have met the validity and reliability of adequate instruments. The results of this study can be used as a reference for further research that will use the e-learning variable.

The confirmatory factor analysis (CFA) also proved that the factors proposed in the measurement model have been confirmed in accordance with previous research, which stated that the factors that affect SDRL (self-directed learning) consist of awareness, learning strategies, learning activities, evaluation, and interpersonal skills (Cadorin et al., 2013; Cazan \& Schiopca, 2014; Williamson, 2007). This study also reveals that SDRL (self-directed learning) is significantly influenced by e-learning or online learning, this result is consistent with research that focuses on developing self-directed learning through online learning 
(Beach, 2017). Measurement of self-regulated learning variables, which in their dimensions consist of environment structuring, goal setting, strategic tasks, time management, helpseeking and self-evaluation, all of these factors meet the criteria of the measurement model, with good validity and reliability, in accordance with the adaptation of regulated learning instruments in previous research (Barnard et al., 2009). The results of hypothesis testing statistically showed that there is no significant influence of online learning towards selfregulated learning. The previous research, it did not discuss how online learning affects selfregulated learning, this study only discussed the measurement model of self-regulated learning in online learning. The results of this study indicated that self-regulated learning is significantly influenced by self-directed learning which is significantly influenced by online learning. Seeing these results, it can be concluded that increasing self-regulated learning with online learning needs to be done by paying attention to the factors forming SDRL (selfdirected learning), which are awareness, learning strategies, learning activities, evaluation, and interpersonal skills.

Self-directed learning is a process in which individuals take the initiative, with or without the help of others, in diagnosing their learning needs, formulating learning goals, identifying human and material resources, selecting and implementing the appropriate ones that fit the learning strategies, and evaluating learning outcomes (Bracey, 2010). Meanwhile, self-regulated learning in a broad sense, is if learners can be free to decide what, when, where, and how to learn. Self-regulated learning is defined as the extent to which students participate in metacognitive, motivation, and behavior in their learning process. From a social cognitive perspective, self-regulated is viewed as a triadic personal interaction, behavior, and environment, and simultaneity (Bracey, 2010). Look back at the notions of self-directed and regulated learning, it seems that online learning carried out in social studies education has not touched on the aspects that develop the way students manage their learning process (self-regulated learning). However, online learning conducted on social studies students was able to contribute $62.8 \%$ to their self-directed learning.

Next, it will be discussed regarding self-determined skills which are the manifest variable in this study. After conducting confirmatory factor analysis, it can be stated that selfefficacy, communication, collaboratively, creativity, positive value, discipline, and responsibility can measure self-determined skills. Measurement instruments meet the standards of very well validity and reliability. Self-regulated learning has the greatest influence on self-determined learning skills, this is indeed appropriate because regulated characteristics are the beginning of self-determined learning skills, it means that if the beginning of online learning significantly affects self-directed learning, it will have an influence on self-determined learning through self-regulated learning. The model proposed is as follows $\mathrm{Y} 2=0.589 \mathrm{X} 2+0.688 \mathrm{Y} 1$. This means that $\mathrm{Y} 2$ is influenced by 0.589 self-directed learning and 0.688 self-regulated learning.

The results of this study contribute clarification of the relationship between selfdirected and self-regulated learning which is, considered ambiguous (Bracey, 2010). This study had confirmed that there is a significant effect between self-directed and self-regulated learning. Another result presents support for the theory of experiential learning (Kolb, 2015) because it determines that experience-based and individual learning activities will be; able to improve cognitive development and change how learning becomes more independent. Elearning was design for students to do independent learning activities. Students must construct knowledge by social interaction experience (Lasfeto \& Ulfa, 2020), find information independently (Mamun et al., 2020). Both of these, establish improved student heutagogy skills. This summary can be fundamental to design e-learning which is improved heutagogy skills. The recommendation of this research had supported by earlier research. If a goal is to improved heutagogy skills, e-learning should focus on metacognitive development 
(Cole, 2020), self-motivation (Chemsi et al., 2020), and self-monitoring assessment (Baird, 2020; Cho et al., 2020).

Online learning seems to have a big impact on students' learning abilities because it emphasizes independence and looks for the best learning process according to each individual. Independent learning is very closely related to adult human learning, therefore, with online learning, skills that are actually needed in the 21 st century will appear. To have a more significant impact on the development of independent learning skills, it seems that lecturers and students need to fully understand the duties and functions when this online learning process is carried out. Adult learners must be actively involved in the teaching, learning, and building of their knowledge; Adult educators and trainers must be able to effectively guide adult learners and their quest for knowledge and skills, to assess and evaluate understanding, and to know what to do when adult learners (and themselves) need more information. Another important focus is on adult educators' reflection because it is also important for adult educators to learn in relation to lifelong learning (Kellenberg et al., 2019).

\section{CONCLUSION}

The results of this study evidenced that e-learning has a significant influence on selfdirected learning. However, e-learning does not directly impact self-regulated learning, the impact of e-learning will be significant if it is through the process of self-directed learning. Self-determined skills were significantly influenced by self-directed and self-regulated learning. It means, if students want to have independent learning, lecturers as designers, facilitators, and evaluators of e-learning, must strive to create online learning that is oriented to the formation of self-directed learning, therefore, other independent learning skills such as self-regulated and self-determined learning will develop. The results of this study also provided an empirical basis for other researchers who want to develop independent learning in students through e-learning. Indicators in self-directed learning can be developed in an online learning process, hence, it can be observed directly on student learning outcomes.

\section{ACKNOWLEDGMENTS}

Thanks, are given to the Faculty of Social Science and Law and LPPM State University of Surabaya for funding for this research. Appreciation also goes to the research team of the Social Studies Education students of UNESA who have participated in this research.

\section{REFERENCES}

Aparicio, M., \& Bacao, F. (2013). E-learning concept trends. ACM International Conference Proceeding Series, 81-86. https://doi.org/10.1145/2503859.2503872.

Arbor, A., \& Greet, D. (2000). Handbook of Self-Regulation. Handbook of Self-Regulation, 451-502. https://doi.org/10.1016/B978-012109890-2/50043-3.

Baird, A. M. (2020). The Self-Determined Student: Teaching Students With Exceptional Needs Self-Determination Through Class-Wide Self-Monitoring through Class-Wide Self-Monitoring [California State University]. https://digitalcommons.csumb.edu/caps_thes_all\%0AThis.

Barnard, L., Lan, W. Y., To, Y. M., Paton, V. O., \& Lai, S. L. (2009). Measuring selfregulation in online and blended learning environments. Internet and Higher Education, 12(1), 1-6. https://doi.org/10.1016/j.iheduc.2008.10.005.

Beach, P. (2017). Self-directed online learning: A theoretical model for understanding 
elementary teachers ' online learning experiences. Teaching and Teacher Education, 61, 60-72. https://doi.org/10.1016/j.tate.2016.10.007.

Blaschke, L. M. (2013). E-Learning and Self-Determined Learning Skills. In Self-Determined Learning Heutagogy in Action (pp. 55-68). Bloomsbury Academic.

Boekaerts, M., \& Boekaelrts, M. (2017). Self-regulated Learning: Bridging the Gap between Metacognitive and Metamotivation Theories. Educational Psychologist, 30(4), 195200. https://doi.org/10.1207/s15326985ep3004.

Bracey, P. (2010). Self-directed learning vs. self-regulated learning: twins or just friends? A comparative review of literature. Proceedings of World Conference on E-Learning in Corporate, Government, Healthcare, and Higher Education 2010, 1, 1600-1607. http://www.editlib.org/p/35780.

Brookfield, S. D. (2009). Self-Directed Learning. In International Handbook of Education for the Changing World of Work (pp. 2615-2627). https://doi.org/10.1007/978-14020-5281-1.

Cadorin, L., Bortoluzzi, G., \& Palese, A. (2013). Nurse Education Today The Self-Rating Scale of Self-Directed Learning ( SRSSDL ): A factor analysis of the Italian version. YNEDT, 33(12), 1511-1516. https://doi.org/10.1016/j.nedt.2013.04.010.

Can, M. (2012). E-heutagogy for lifelong e-learning. 1, 129-131. https://doi.org/10.1016/j.protcy.2012.02.025.

Cazan, A., \& Schiopca, B. (2014). Self-directed learning, personality traits and academic achievement. Procedia - Social and Behavioral Sciences, 127, 640-644. https://doi.org/10.1016/j.sbspro.2014.03.327.

Chemsi, G., Sadiq, M., Radid, M., \& Talbi, M. (2020). Study of the self-determined motivation among students in the context of online pedagogical activities. International Journal of Emerging Technologies in Learning, 15(5), 17-29. https://doi.org/10.3991/IJET.V15I05.11392.

Cho, H. J., Levesque-Bristol, C., \& Yough, M. (2020). International students' selfdetermined motivation, beliefs about classroom assessment, learning strategies, and academic adjustment in higher education. Higher Education. https://doi.org/10.1007/s10734-020-00608-0.

Cole, A. W. (2020). Engagement in metacognition within self-determined learning. CHIIR 2020 - Proceedings of the 2020 Conference on Human Information Interaction and Retrieval, 495-498. https://doi.org/10.1145/3343413.3377943.

Esham, B., \& Abdul, F. (2010). Self-directed Learning and Culture : A Study on Malay Adult Learners. Procedia Social and Behavioral Sciences, 7(C), 254-263. https://doi.org/10.1016/j.sbspro.2010.10.036.

Garrison, D. R. (1997). Self-directed learning: Toward a comprehensive model. Adult Education Quarterly, 48(1), 18-33.

Haryono, N., \& Octavia, R. (2020). Analisis Pengaruh Citra Merek Dan Mutu Layanan Terhadap Kepuasan Konsumen Serta Dampaknya Terhadap Loyalitas Konsumen. INDEPT, 4(1), 20-27.

Hase, S. (2016). Self-determined Learning (heutagogy): Where Have We Come Since 2000 ? Special Edition of Southern Institute of Technology Journal of Applied Research, 21(May).

Hase, S., \& Kenyon, C. (2013). Self-Determined Learning. Bloomsbury Academic.

Kellenberg, F., Schmidt, J., \& Werner, C. (2019). The Adult Learner: Self-Determined, SelfRegulated, and Reflective. Journal of Pedagogy and Psychology "Signum Temporis," 9(1), 23-29. https://doi.org/10.1515/sigtem-2017-0001.

Kolb, D. A. (2015). Experiential Learning: Experience as the Source of Learning and Development. In Pearson Education, Inc. Pearson Education, Inc. 
Kulakow, S., \& Raufelder, D. (2020). Enjoyment benefits adolescents' self-determined motivation in student-centered learning. International Journal of Educational Research, 103(June), 101635. https://doi.org/10.1016/j.ijer.2020.101635.

Lasfeto, D. B., \& Ulfa, S. (2020). The relationship between self-directed learning and students' social interaction in the online learning environment. Journal of E-Learning and Knowledge Society, 16(2), 34-41. https://doi.org/10.20368/1971-8829/1135078.

Mamun, M. A. Al, Lawrie, G., \& Wright, T. (2020). Instructional design of scaffolded online learning modules for self-directed and inquiry-based learning environments. Computers and Education, 144(December 2018), 103695. https://doi.org/10.1016/j.compedu.2019.103695.

Martin, J. (2004). Self-Regulated Learning, Social Cognitive Theory, and Agency. Educational Psychologist, 39(July 2015), 111-133. https://doi.org/10.1207/s15326985ep3902.

Müller, F. H., \& Louw, J. (2004). Learning environment, motivation and interest: Perspectives on self-determination theory. South African Journal of Psychology, 34(2), 169-190. https://doi.org/10.1177/008124630403400201.

Pintrich, P. R. (1995). Understanding self-regulated learning. New directions for teaching and learning, 1995(63), 3-12. https://onlinelibrary.wiley.com/doi/abs/10.1002/t1.37219956304.

Pintrich, P. R. (2000). The role of goal orientation in self- regulated learning. In Handbook of self-regulation (pp. 451-502). Academic Press.

Reed, T. (2014). Thinking Maps: An Innovative Way To Increase Sixth-Grade Student Achievement In Social Studies (Issue July). Capella University.

Robinson, J. D., \& Persky, A. M. (2020). Developing self-directed learners. American Journal of Pharmaceutical Education, 84(3), 292-296. https://doi.org/10.5688/ajpe847512.

Schunk, D. H. (1995). Inherent details of self-regulated learning include student perceptions. Educational Psychologist, 30(4), 213-216. https://doi.org/10.1207/s15326985ep3004.

Schunk, D. H. (2010). Self-Regulated Learning: The Educational Legacy of Paul R . Pintrich. Educational Psychologist, 40(2), 85-94. https://doi.org/10.1207/s15326985ep4002.

Sinatra, G. M. (2014). The Legacy and the Challenges: Paul Pintrich's Contributiosn to Personal Epistemology Research. Educational Psychologist, 1520(August), 37-41. https://doi.org/10.1207/s15326985ep4002.

Williamson, S. N. (2007). Development of a self-rating scale of self-directed learning. Nurse Researcher, 14(2), 66-83.

Winne, P. H. (2015). Self-Regulated Learning. In International Encyclopedia of Social \& Behavioral Sciences (Second Edi, Vol. 21, Issue 2, pp. 535-540). Elsevier. https://doi.org/10.1016/B978-0-08-097086-8.25091-5.

Winne, P. H. (2016). Improving Measurements of Self-Regulated Learning. 1520(December). https://doi.org/10.1080/00461520.2010.517150.

Zhoc, K. C. H., \& Chen, G. (2016). Reliability and validity evidence for the Self-Directed Learning Scale (SDLS). Learning and Individual Differences, 49, 245-250. https://doi.org/10.1016/j.lindif.2016.06.013.

Zimmerman, B. J. (1990). Self-Regulated Learning and Academic Achievement: An Overview Self-Regulated Learning and Academic Achievement: An Overview. Educational Psychologist, 25(1), 3-17. https://doi.org/10.1207/s15326985ep2501. 